\title{
The Size of the Rental Market and Housing Market Fluctuations
}

\author{
Adam Czerniak $^{1} \cdot$ Michał Rubaszek $^{2}$
}

(C) The Author(s) 2017. This article is an open access publication

\begin{abstract}
The paper investigates whether the size of the rental market affects house prices fluctuations or the volatility of construction sector activity over the business cycle. For that purpose we construct a database of variables describing the housing sector in a group of twelve initial euro area members and ten other OECD countries over the years 1995-2014 and conduct a series of panel regressions. We find that a developed rental market attenuates fluctuations in the housing sector, especially for the common currency area sample. We claim that differences among monetary union countries in terms of rental market developments can be destabilizing as they might lead to heterogeneous response to common shocks.
\end{abstract}

Keywords Rental market $\cdot$ Housing sector $\cdot$ Panel data $\cdot$ Monetary union

JEL classification $\mathrm{C} 23 \cdot \mathrm{F} 45 \cdot \mathrm{O} 18$

\section{Introduction}

The relationship between the situation in the housing sector and the macroeconomic stability is the subject of numerous studies (Catte et al. 2004; André and Girouard 2009; Agnello and Schuknecht 2011). According to Leamer (2007) fluctuations in the housing market activity are the core cause of the business cycle and the data on residential investment can be successfully used as an early warning sign of an oncoming recession. For that reason a lot of effort has been devoted to analyze the impact of house price fluctuations on different aspects of the economy: the volume of consumption and investment (Case et al. 2005), the allocation of means of production (OECD

Michał Rubaszek

mrubas@sgh.waw.pl

1 SGH Warsaw School of Economics, al. Niepodleglosci 162, Warszawa 02-554, Poland

2 Narodowy Bank Polski, ul. Swietokrzyska 11/21, 00-919 Warszawa, Poland 
2005) or the supply of credit in the banking sector (Bernanke et al. 1996). The importance of the housing market is also discussed in studies on monetary integration, especially in the context of asymmetric responses of individual economies to demand shocks affecting the real estate market (Maclennan et al. 1998) or in the context of the impact of interest rate cuts on the creation of imbalances in the housing markets in Spain and Ireland after euro accession (Conefrey and Gerald 2010; Rubio 2014). There are also some overview analyses on the importance of the housing market structure and its dynamics for the transmission of monetary policy impulses to the economy (Iacovello and Minetti 2008) as well as for the efficiency of countercyclical monetary, fiscal and macroprudential policies (Crowe et al. 2013).

Even though the literature on the role of the housing market in the economy is extensive, the number of studies analyzing the role of the rental market is scarce. A few papers, which focus on individual countries, show that the development of the rental market affects the flexibility of the housing sector, hence is important for the resistance of the economy to shocks (Kofner 2014; IMF 2009). There are few cross-country econometric analyses on the relationship between rental market characteristics and boom-bust cycles in the housing sector. For instance Arce and López-Salido (2011) build a theoretical model to show that the availability of rental housing reduces the risk of a house price bubble. Their results are empirically confirmed by Czerniak (2014), who uses a panel logit model for a group of developed countries to show that institutional and socio-cultural factors, including the size of the rental market, influence the probability of a housing bubble. More insight on this matter has been provided by Cuerpo et al. (2014), who analyze how private rental market regulations (i.e. different aspects of rent controls and tenant-landlord regulations) influence the response of house prices to four socio-economic determinants: population growth rate, income dynamics, housing investment as well as fluctuations in real long-term interest rates. They indicate that stricter rent controls increase the response of house prices to changes in all the explanatory variables. On the other hand, their results point that tenant-landlord regulations are of lower importance.

Another strand of the literature investigates the relationship between the structure of the rental market and labor mobility. For example, Caldera Sánchez and Andrews (2011) find that an increase in the availability of rental housing leads to higher residential mobility, hence to more efficient allocation of the labor force. Similarly, Barceló (2006) estimates that at an individual level labor mobility, defined as a change in the employment status, is considerably smaller for an owner than for a private tenant. Furthermore, she shows that social housing tenants are less mobile in comparison to tenants in the private market. These results suggest that an effective rental market should decrease the vulnerability of the economy to demand fluctuations, and in the long-term horizon should also diminish the level of structural unemployment. This hypothesis has been empirically tested by Blanchflower and Oswald (2013), who run a panel data regression to explain the differences in the unemployment rate across US states. They find that a rise in the homeownership rate is a good predictor of the subsequent increase in unemployment. As indicated by the authors, the potential reasons of this relationship are not limited to the lower level of labor mobility, as in Barceló, but also due to greater commuting times (areas with more homeowners experience greater transport congestion) and fewer new businesses in states with larger owner-occupation ratio, which is due to resistance of homeowners against new factories in their neighborhood. 
We contribute to the above literature by analyzing how differences in the development of the rental housing market across European Monetary Union (EMU) countries affect business cycle synchronization. For that purpose we test whether the size of the rental market has an impact on house prices fluctuations and the variability of activity in the construction sector. In particular, we investigate if differences in rental housing availability influence how the housing sector reacts to demographic, demand and monetary shocks across European Monetary Union (EMU) countries. Towards this goal we construct a database for twelve EMU member states over the years 1995-2014 and run a set of panel regressions. Our main result is that the size of the rental market is an important determinant of house price dynamics and the volatility of activity in the construction sector. In the sensitivity analysis we extend our sample for ten other OECD countries ${ }^{1}$ to check if the size of the rental market affects economic fluctuations also outside EMU. The empirical results are complemented with discussion on how heterogeneous developments in the rental market across member states of the euro area might affect the stability of the entire region.

The rest of the paper is organized as follows. The next section describes the tenure structure of the housing market across EMU member states and its correlation with selected indicators of housing market and macroeconomic stability. Section 3 discusses the specification of panel regressions and estimation strategy. Section 4 presents the baseline results of panel data regression for EMU countries. The sensitivity analysis with respect to changes in estimation method or country coverage is included in Section 5 The last section concludes and provides some interpretation of the results in the form of possible policy interpretation.

\section{Rental Market and Economic Fluctuations in EMU Countries}

This section aims at presenting data related to the size of the rental market in the EMU countries. We start by defining rental housing (in line with the definition within European Union Statistics on Income and Living Conditions, EU-SILC) as all houses that are occupied by non-owners, who pay a market rent, a reduced rent or can use the accommodation for free (e.g. the accommodation comes with the job or is provided rent-free from a private or public source). In this sense the definition of rental housing includes different forms of social housing but exclude co-operatives. For this kind of definition the availability of rental housing differs largely across the twelve EMU countries. According to Eurostat EU-SILC data, ${ }^{2}$ which are presented in Fig. 1, the

\footnotetext{
${ }^{1}$ Australia, Canada, Denmark, Japan, Korea, New Zealand, Norway, Switzerland, Sweden, United States, United Kingdom.

2 There are large discrepancies between different sources of tenure status data (up to over $10 \mathrm{pp}$. for rental housing share for EMU countries). The most reliable data are provided within national censuses, which cover the largest share of population. However they are of limited usefulness for panel regressions due to very low frequency of dissemination (on average once every decade). Higher frequency data with the largest coverage for EMU countries are provided by Eurostat within the EU-SILC. This database contain statistics describing the share of population living in rental housing. However, these statistics have data gaps for years 1995-2014. We decided to interpolate the EU-SILC database and extrapolate it with the use of other data sources - i.e. OECD Housing Market questionnaire (Andrews et al. 2011) and national censuses data as provided by the United Nations Statistics Division. This method is justified as the size of the rental market has very small variance in time (the average standard deviation among EMU countries between 1995 and 2014 is 2.70 pp.). In those few cases in which other data sources were not available we used the linear interpolation and extrapolation method.
} 


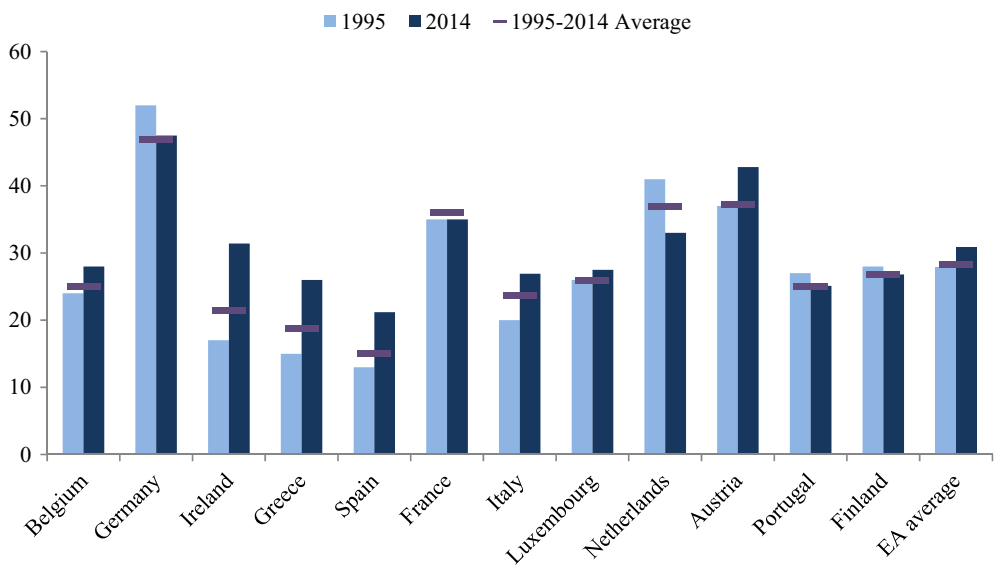

Fig. 1 The share of rental market in EMU countries (\%). Source: Eurostat, OECD, UN, own calculations

average size of the rental market over the period 1995-2014 was the highest in Germany, where $47 \%$ of households were tenants, and the lowest in peripheral countries like Spain (15\%), Greece (19\%) and Ireland (22\%). The dispersion of this ratio between the countries was about four times larger than the time dispersion within individual countries: the average standard deviation in time for each country is equal to 2.70 p.p. and the average standard deviation across EMU states in each period amounts to 10.96 p.p. One can therefore conclude that the size of the rental market usually changes only gradually, which would indicate that the observed differences across EMU member states will most likely prevail in the forthcoming decades. In this context it is worth noticing, however, that after the global financial crisis and the bursting of housing market bubbles across European countries the diverging tendencies in the size of the rental market have reversed. The main reason are the developments across peripheral countries, where a large fraction of households was cut-off from credit financing and wasn't able to satisfy their housing needs through acquiring a real estate. For example, in Ireland the share of tenants grew rapidly from $23 \%$ in 2008 to $30 \%$ in 2011 and stabilized at this value afterwards.

Looking closely at the composition of rental housing supply, which is illustrated in Fig. 2, one can observe that in EMU countries about two thirds of tenants pay market rent and one third of them pay reduced rent $(20 \%$ versus $10 \%$ of all households in 2014). The only exceptions are Finland and Portugal, where more people enjoy belowmarket rents than regular ones, which is an effect of relatively high availability of social housing and rent subsidies in both countries.

To analyze how the above differences in the rental housing sector across EMU countries can lead to cyclical divergence, let us notice that houses play a dual role: they are an investment vehicle and at the same time they provide utility from housing services. Renting allows to separate these roles. For a landlord a house is an investment and for a tenant it provides utility. Even though rental housing is an alternative to homeownership in satisfying housing needs (Sinai and Souleles 2005), the size of the rental market can affect investment decisions, hence economic fluctuations over the business cycle. To investigate this we put forward two theses. 


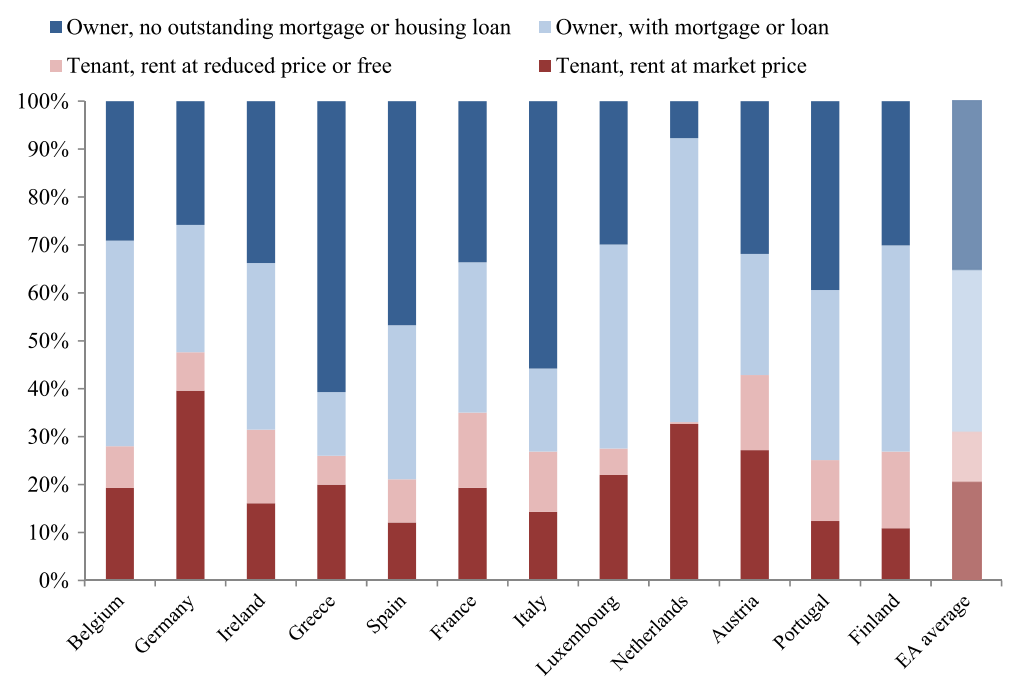

Fig. 2 The structure of the housing market in EMU countries in 2014. Source: Eurostat

Thesis 1. An increase in the size of the rental market diminishes the effect of aggregate demand fluctuations on house prices For example, in the case of a demographic boom the rental market can absorb a part of the increase in demand for housing that would otherwise translate into a sharp swing in real estate prices, fueling a housing bubble (Czerniak 2016). This claim is especially relevant if a part of the increase in the demand for houses is already discounted in house prices, but not in the level of rents. This is not a strong assumption as misalignments and its corrections occurs mainly through prices, not rents (Ambrose et al. 2013). In such a case, according to the portfolio model of tenure choice (Mills 1990), the relative demand for owneroccupied houses should be attenuated. However, the necessary condition is that renting is a feasible alternative to owning in satisfying housing needs. Furthermore, rental housing can also diminish the effects of monetary or financial shocks. Without a developed rental market, there could be a large fraction of households that are financially constrained and cannot adjust the size of their apartment to their needs: they do not have sufficient funds to make a down-payment or their creditworthiness is too low to take a mortgage. These households are forced to limit the size of their owned house or cohabit until financial conditions are more favorable. Eventually, when monetary policy eases and housing credit affordability increases a large amount of buyers rush simultaneously to the housing market, boosting demand, which fuels large price increases (Favara and Imbs 2015). An effective rental market should serve as a factor attenuating the impact of monetary and collateral constraint shocks on house prices. The reason is that households living in rented houses are less constrained in fitting the size of the occupied apartment to their needs, hence the number of households that try instantly to switch to homeownership or increase the size of their apartment when their creditworthiness increase is lower. This reduces the risk of large fluctuations in house prices over the business cycle, as inelastic housing supply has more time to adjust to a gradual increase in housing demand (Caldera Sánchez and Johansson 2011; Rubaszek and Rubio 2017). 
Thesis 2. The size of the rental housing should attenuate fluctuations in construction sector activity over the business cycle It might be argued that a large rental housing sector can even induce the existence of countercyclical swings in real estate activity. The reason is that the behavior of landlords and homeowners is different. For landlords buying a house for renting is treated as an investment and the decision based predominantly on expected rate of return and perceived risk. For that reason it might be the case that price increases in times of a housing boom discourage investors from buying houses and price decreases after a bust, especially when they are accompanied by interest rate cuts, are motivating investors to enter into the rental market. This process is also supported by a change in households' preferences on tenure choice as relatively more people are willing to rent than to buy during recessions. The explanation is that private ownership of mortgaged property is less available and deemed more risky.

Apart from the above two theses, the literature review from the Introduction indicates that a larger rental market fosters higher labor mobility, which in turn might reduce structural unemployment. Moreover, lower volatility of the housing sector due to the existence of the efficient rental market can contribute to lower volatility of investment and aggregate output.

A glance at the available data for twelve EMU economies over the years 19952014, which are described in Table $1,{ }^{3}$ allows for claiming that countries with developed rental housing market were in general more stable than the countries with high homeownership ratio (Table 2). The first two rows of Table 2 show that there is a negative correlation between the size of the rental market and house price volatility, which somewhat confirms thesis 1, and that the average EUR price of squared meter is almost uncorrelated with the tenure structure of the housing market. The next two rows of the table indicate that the volatility of activity in the construction sector and the size of the rental market are strongly and negatively correlated, which supports thesis 2. As in the case of house prices, there is no significant relationship between the size of the rental market and the share of the construction sector in total value added. That would suggest that supporting rental housing availability through appropriate residential policy most likely won't lead (in a medium-run) to a decrease in the size of the construction sector, as some politicians tend to believe. Finally, the last row of the table shows that the correlations between the share of rental houses and output volatility is also negative. This informally indicates that larger availability of rental housing can act as an automatic stabilizer for the economy as it attenuates business activity fluctuations resulting from swings in aggregate demand.

\section{Panel Regressions Specification and Estimation Strategy}

In the previous section we have illustrated that correlations between the size of the rental market and both real house prices volatility and the variability of construction sector activity are negative. It should be noted, however, that these relationships could be distorted by other factors, which cannot be accounted for in a simple correlation analysis. In this section we address this issue by using panel data regressions, which

\footnotetext{
${ }^{3}$ A detailed description of the dataset is provided in the next section.
} 
Table 1 Data sources

\begin{tabular}{|c|c|c|}
\hline Variable name & Variable description & Data source \\
\hline $\mathrm{rms}$ & Share of rental houses in total occupied housing units (\%) & $\begin{array}{l}\text { Eurostat SILC/UN } \\
\text { Yearbooks/national } \\
\text { sources }\end{array}$ \\
\hline pop & Total population as of 1 of January & $\begin{array}{l}\text { Eurostat/UN World } \\
\text { Population Prospects }\end{array}$ \\
\hline pop_20_34 & Population in the age of 20 to 34 as of 1 of January & $\begin{array}{l}\text { Eurostat/UN World } \\
\text { Population Prospects }\end{array}$ \\
\hline popsh & $\begin{array}{l}\text { Share of population in the age of } 20 \text { to } 34 \text { as of } 1 \text { of } \\
\text { January (\% total population) }\end{array}$ & own calculations \\
\hline hp & Index of real house prices $(2010=100)$ & OECD/BIS \\
\hline GDP_cs10 & GDP in constant prices from 2010 & Eurostat/OECD \\
\hline invest_cs10 & Gross fixed capital formation in constant prices from 2010 & Eurostat/OECD \\
\hline u_rate & Unemployment rate for the $16-64$ years old cohort & Eurostat LFS/OECD \\
\hline nairu & NAIRU unemployment rate $(\%)$ & $\begin{array}{l}\text { OECD Economic } \\
\text { Outlook no. } 100\end{array}$ \\
\hline ir & $\begin{array}{l}\text { Real long-term bond yields (ca. } 10 \text { years) deflated by } \\
\text { HICP inflation }\end{array}$ & OECD/Eurostat/IMF IFS \\
\hline immigrants & $\begin{array}{l}\text { Annual net immigration (immigration minus emigration) } \\
\text { as a share of total population (\%, interpolated from } \\
5 \text {-year data with cubic-match sum interpolation method) }\end{array}$ & World Bank WDI \\
\hline gap & Output gap (\% of actual GDP) & $\begin{array}{l}\text { OECD Economic } \\
\text { Outlook no. } 100\end{array}$ \\
\hline sn & Short-term interbank interest rates (3-month LIBOR rates) & OECD/IMF IFS \\
\hline $\mathrm{sr}$ & $\begin{array}{l}\text { Real short-term interbank interest rates (3-month LIBOR } \\
\text { rates) deflated by HICP inflation }\end{array}$ & OECD/Eurostat/IMF IFS \\
\hline vac & $\begin{array}{l}\text { Share of value added in the construction sector } \\
\text { (\% total value added in current prices) }\end{array}$ & Eurostat/OECD \\
\hline urban_pop_s & Share of total population living in urban areas $(\%)$ & World Bank WDI \\
\hline
\end{tabular}

allow to control for other factors that affect the housing sector. In particular we estimate the parameters of the following models:

$$
\begin{aligned}
& \Delta h p_{i t}=\alpha_{1} \text { gap }_{i t}+\alpha_{2} \text { rms }_{i, t-1}+\alpha_{3} \text { interest }_{i t}+\alpha_{4} \text { demo }_{i t}+\gamma \text { inter }_{i t}+\phi_{i}+\epsilon_{i t} \\
& \text { vac }_{i t}=\beta_{1} \text { gap }_{i t}+\beta_{2} \text { rms }_{i, t-1}+\beta_{3} \text { interest }_{i, t}+\beta_{4} \text { demo }_{i, t}+\delta \text { inter }_{i t}+\psi_{i}+\eta_{i t}
\end{aligned}
$$

where $i$ and $t$ are country and time indices, $\phi_{i}$ and $\psi_{i}$ denote country fixed effects, whereas $\epsilon_{i t}$ and $\eta_{i t}$ stand for the error terms. Model (1) describes the dynamic of log real house prices $(h p)$ as a function of output gap expressed as a percentage of GDP ( gap), the share of households living in rented apartments $(\mathrm{rms})$, a monetary policy stance indicator (interest), demographic factors (demo) and an interaction variable that captures the indirect effects of rental housing availability (inter). The specification of model (2) is identical to the specification of model (1) up to the dependent variable, which is the ratio of the nominal value added in the construction sector to the total value added in the economy. The estimates of parameters $\gamma$ and $\delta$ are the main focus of our analysis, as they measure whether the size of the rental sector amplifies or mitigates the impact of a given explanatory variable 
Table 2 Correlations with the rental market share (across 12 EMU countries, for period 1995-2014)

Correlation with rms (period average)

\begin{tabular}{ll} 
Real house price growth rate, period average & $-0,12$ \\
Real house price growth rate, period std. deviation & $-0,53$ \\
Share of construction sector in value added, period average & $-0,50$ \\
Share of construction sector in value added, period std. deviation & $-0,51$ \\
Real GDP growth rate, period average & $-0,17$ \\
Real GDP growth rate, period std. deviation & $-0,52$ \\
\hline
\end{tabular}

Source: see Table 1

on the housing sector dynamics. It is worth noting that output gap takes into account many factors, including global determinants of the housing market, the role of which is emphasized indicated in other studies (Gete 2010; Agnello and Schuknecht 2011). For example, an inflow of foreign investment to the housing sector, which is reflected in current account deterioration, leads to both higher output gap and house prices increase.

Models (1) and (2) are estimated in static and dynamic form, where the latter also includes the lagged dependent variable in the set of regressors. As regards the choice of explanatory variables, it is generally based on the previous literature (Agnello and Schuknecht 2011; Czerniak and Witkowski 2016). In particular we use the following series, which we divide into two groups:

- Monetary policy stance indicators (interest):

a. short-term nominal interest rates measured by 3-month interbank lending rate $(s n)$ and its first difference $(\Delta s n)$,

b. short-term real interest rates measured by 3-month interbank lending rate deflated by current HICP inflation $(s r)$ and its first difference $(\Delta s r)$,

c. long-term real interest rates measured by 10 -year bond yield deflated by current HICP inflation (ir) and its first difference $(\Delta i r)$.

- Demographic indicators (demo):

a. total population growth rate $(\Delta p o p)$,

b. growth rate of population in household formation age of 20-34 years ( $\triangle$ pop_20_34),

c. net annual immigration as a percent of total population (immigrant).

d. the share of population in household formation age (popsh),

e. the share of population living in urban areas (urban).

Moreover, in the specification of the model we test the following interaction variables (inter):

a. the product of rental market share and the output gap $\left(r m s_{-1} \times g a p\right)$, which describes how rental housing availability amplifies the effect of cyclical fluctuations on the real estate market dynamics, 
b. the product of rental market share and a monetary policy stance indicator $\left(r m s_{-1} \times\right.$ interest), which describes whether the rental housing availability affects the response of the housing market to financial conditions changes,

c. the product of rental market share and a demographic indicator $\left(\mathrm{rms}_{-1} \times\right.$ demo $)$, which describes how the rental housing availability affects the reaction of the real estate market indicators on demographic shocks,

d. the product of the rental market share and the lagged dependent variable (rms ${ }_{-1} \times \Delta h p_{-1}$ or $\left.r m s_{-1} \times \operatorname{vac}_{-1}\right)$, which describes the influence of the rental housing availability on the persistence of the housing market dynamics.

The specification selection and estimation consist of four steps. First, we run standard fixed effects (FE) panel data regressions for a static model to determine the optimal set of regressors and check for the statistical significance of the interaction variable. In particular, from each of the above two groups of regressors we choose one explanatory variable so that the fit of the model is the highest and the estimated parameter is of expected sign. Having set interest and demo variables we add one interaction variable and test for its significance. Second, we estimate dynamic models (with lagged dependent variable) and a set of regressors defined in the previous step using standard FE estimator. In this way we check whether the statistical significance of interaction variables holds in a dynamic setup. Third, we take our preferred dynamic specification and perform a sensitivity analysis by comparing various estimation procedures: FE estimator with bootstrap standard errors (FE-BS), FE estimator corrected for the Nickel bias as proposed by Bruno (2005, FE-BC), first-difference instrumental variable estimator proposed by Anderson-Hsiao (1982, AH) and the Arellano-Bond (1991, AB) GMM estimator. Forth, we compare FE-BC estimates for two groups of countries: twelve EMU states and all 22 OECD countries.

Before discussing estimation results, it is worthy to discuss how we tackle the inclusion of the interaction variable. In this respect two issues are important. Frist, the strong-heredity principle, which states that the use of an interaction variable $x_{1} \times x_{2}$ requires also the use of both variables $x_{1}$ and $x_{2}$ among the set of control variables, needs to be respected (Nelder 1998). Otherwise restrictions imposed on regression parameters are often unjustifiable and the conditions required to have unbiased and effective estimators are very restrictive. Second, respecting the strong-heredity principle often means that one has to tackle the problem of multicollinearity, especially if one of variables $x_{1}$ or $x_{2}$ is relatively invariant in time, as is the case for the rental market size $(r m s)$. This diminishes the precision of estimates and makes standard $t$-statistics unsuitable to assess the statistical significance of the additional variable (Farrar and Glauber 1967). To overcome this problem we test whether the extended model is significantly better fit to the data than the baseline specification (without the interaction variable) by using the likelihood ratio (LL-ratio) test.

\section{The Results}

\subsection{Data}

The parameters of regression (1) and (2) are estimated on the basis of annual data from the period 1995-2014 covering twelve EMU economies and ten other OECD member. 
Most of the series are taken from Eurostat and OECD databases. The other data sources that were used include UN statistics, the World Bank, International Monetary Fund and national sources, mainly census data obtain from central statistical offices. A detailed list of data sources and series names is provided in Table 1.

\subsection{Results for House Prices Regressions}

In the first stage of the estimation procedure we have found that real house price dynamics is best described by changes in the real long-term interest rates $(\Delta i r)$ compared to other monetary indicators, and by net immigration (immigrant) compared to other demographic factors. It is worth mentioning that short-term interest rates turned out to be statistically insignificant determinant of house price dynamics in EMU countries, which is an astonishing result as in many EMU countries interest rates on mortgages are usually linked to the LIBOR rates. Among demo variables the best fit was found for variable urban, describing the share of population living in urban areas. However, given that the sign of estimated parameter turned out to be negative, which is at odds with the literature (Glaeser et al. 2008), we have decided to use the specification with immigration variable.

The estimation results, which are presented in Table 3, warrant few observations. Let us start by describing the findings for static models, which are described by the left panel of the table. The size of the rental market has no direct effect on the real house price growth rate (parameter at $r m s$ variable). However, the estimates of the parameters at interaction variables show that the size of the rental market alters the strength of house prices reaction to changes in external financing conditions and to immigration. In particular, we find that including the monetary interaction variable $\left(r m s_{i, t-1} \times \Delta i r_{i t}\right)$, which captures how rental housing availability alters the effect of changes in long-term interest rates on house prices, significantly improves the fit of the model to the data at $10 \%$ significance level ( $L L$-ratio test). This provides some evidence supporting thesis 1 , which indicates that the increase in the size of the rental market decreases the impact of financing conditions on the pace of house price growth. The value of the estimated parameter indicates that the impact of interest rate changes on house price dynamics slowly decreases with the size of the rental market and vanishes when the share of rental housing reaches around 30\%. As regards demographic interaction variable (imigrant $\times r m s_{-1}$ ), the parameter estimate has the right sign and is significant at $5 \%$ level. If one analyzes the model estimates in detail, the parameter-indicated influence of immigrants on the housing market is positive in countries, where the share of rental houses is relatively low ( $r m s$ at around 15\%), whereas in countries with high rental housing availability ( $r m s$ at around $40 \%$ ) the inflow of migrants mitigates the rise in house prices. One might explain this phenomena by the fact that in latter countries migrants usually tend to live in social or rental housing, hence their inflow leads to an increase in a supply of publicly-subsidized housing (social and for rent), which might decrease prices of owner-occupied housing.

Let us now discuss the results for dynamic models, which are presented in the right panel of Table 3. In general, the sign and magnitude of estimates of parameters at interaction variables is broadly the same as for the static models. The only difference is that the monetary interaction variable become insignificant. An interesting result is that the sign of the parameter at the interaction variable with the lagged house price dynamics (last column of the table) is negative. It indicates that in countries with 


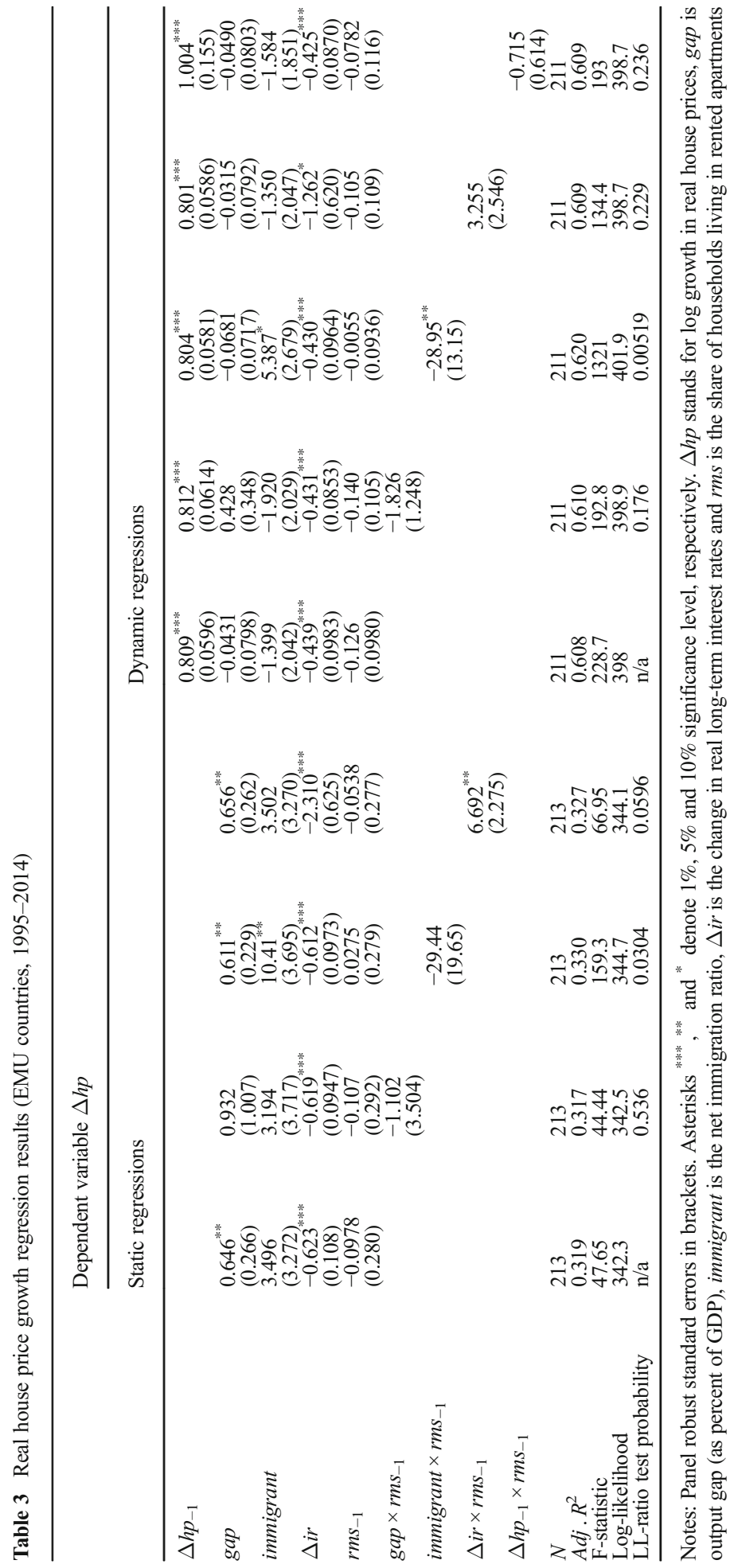


higher rental market share the autocorrelation of house prices is smaller. We claim that this result is important as high autocorrelation increases the risk of housing bubbles (Case et al. 2005). Thus, the estimation results indicate that markets with higher availability of dwellings for rent tend to be more resilient to house price misalignments, which confirms the results of the literature on house bubbles (Czerniak 2014; Kofner 2014; Czerniak and Witkowski 2016).

\subsection{Results for Construction Sector Activity Regressions}

In first stage of the estimation procedure we have found that the best specifications for the static model describing the size of the construction sector ( $\mathrm{vac}$ ) are those that include the change in short-term nominal interest rate $(\Delta s n)$ and the growth rate of population $(\Delta p o p)$. It can be added that the parameters for other demographic variables (immigrant and $\Delta$ pop2034) were significant, but these specifications yielded lower fit of the model.

The estimation results are presented in Table 4. The most important result, both for static and dynamic specifications, is that adding the output gap interaction variable $\left(\right.$ gap $\left.\times r m s_{-1}\right)$ to the set of regressors improves the fit of the model to the data at a $1 \%$ significance level. This provides strong support for thesis 2 , which states that a larger rental housing sector leads to the existence of countercyclical swings in real estate activity, hence to lower sensitivity of the construction sector to its socio-economic environment. Also adding the demographic interaction variable $\left(\Delta p o p \times r m s_{-1}\right)$ enhances the fit to the data. The relevant parameter estimates are of expected sign and their values indicate that in countries with the rental market share standing at around $50 \%$ the impact of the output gap and demographic booms on the size of the construction sector becomes negligible. This might explain why the housing sector in Germany has been so resistant to booms and busts in comparison to other EMU countries for the last two decades. Finally, it can be noted that the parameter estimate at the monetary interaction variable $\left(\Delta s n \times r m s_{-1}\right)$ turned out to be insignificant. Moreover, as in the house price regression case, the sign of the parameter at the interaction variable with the lagged dependent variable is negative, although insignificant. This indicates that the persistence of construction activity might decreases with the size of the rental housing market.

\section{Sensitivity Analysis}

\subsection{Different Estimation Methods}

It is widely known that a standard FE estimator of the autoregressive parameter in dynamic panel models is downward biased (Nickell 1981). A simple solution to take into account the Nickel bias is to apply the bias corrected FE estimator of Bruno (2005, BC-FE). A more sophisticated way to tackle the Nickel bias is to differentiate both sides of model equation to remove the fixed effects. The transformed model on first differences can be estimated with instrumental variable estimator, as proposed by Anderson and Hsiao (1982, AH), or using GMM estimator, as proposed by Arellano and Bond (1991, AB). In both cases, however, the estimators might be ineffective if 


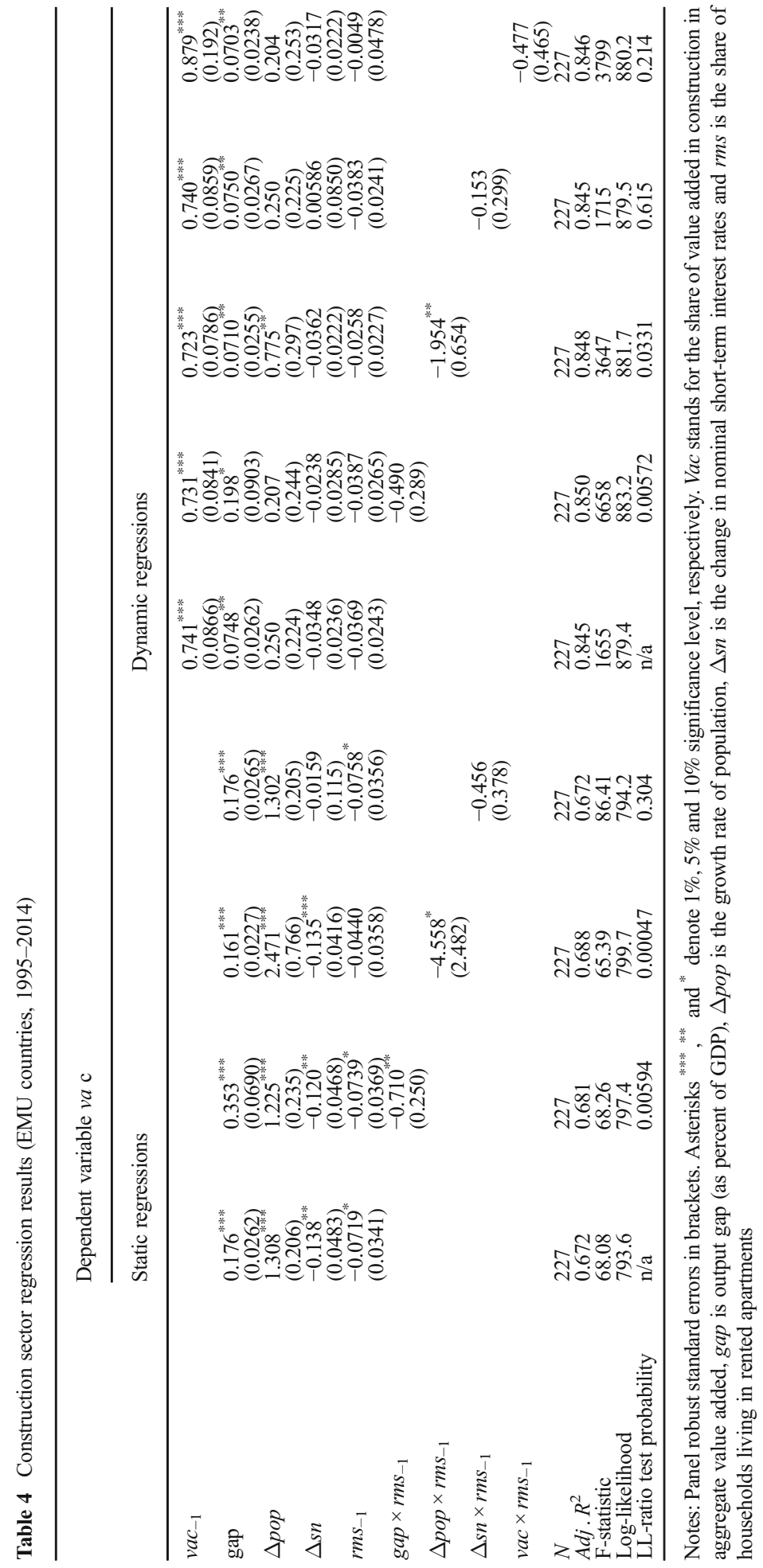


instruments are weak. Finally, we add to the suite of estimation methods the standard FE estimator with bootstrap standard errors, to check whether standard errors for the other methods are reliable.

The results of this sensitivity analysis for the house price regressions with respect to the estimation method are presented in Table 5. The left-side columns of the table show that estimation results in specification with the interaction variable $\Delta i r \times r m s_{-1}$ are very similar across the methods. In all cases, but for FE-BC estimator, tighter financing conditions are significantly diminishing the pace of house prices growth (if $r m s=0$ ) and the impact of interest rates is diminishing with the size of the rental market. The estimates obtained with all methods indicate that for countries in which the share of tenants is around one third ( $r m s=33 \%$ ) the impact of real interest rate changes on house prices becomes close to zero. Moreover, the AH estimator indicates that the monetary interaction variable is significant determinant of house price growth at a $5 \%$ level. In turn, the right-side columns of Table 5 show that the findings for the demographic interaction variable described in the previous section are robust across estimation methods - it is statistically significant in all cases, but for the FE-BT. In particular, the results confirm that immigration inflow increases house price dynamics only in countries with undeveloped rental market.

An analogous sensitivity analysis, with respect to the estimation method, for housing sector activity regressions is presented in Table 6 . The left part of the table shows that parameter estimates of model (2) with the output gap interaction variable $g a p \times r m s_{-1}$, are very similar across all estimation methods, but the Anderson-Hsiao (AH). In all cases the share of the construction sector in value added is procyclical, but this procyclicality diminishes with the size of the rental market. The value of $r m s$ at which there is no relation between vac and gap is in all cases around $40 \%$, which would indicate that in countries with this scale of rental market development the construction sector is not amplifying business cycle fluctuations. What is more, in countries characterized by very high share of tenants, exceeding $40 \%$, the construction sector might even stabilize macroeconomic fluctuations, due to reasons that were discussed in earlier sections. Those findings tend to be even more vivid when one uses the FE-BC or $\mathrm{AB}$ estimation methods, which yield slightly higher parameter values at the interaction variable and much lower standard errors, hence in both cases the interaction variable is significant at a 5\% significance level. Moreover, it should be mentioned that the estimates obtained with these methods also point to a negative relationship between the rental housing availability and the size of the construction sector, which indicate that in some cases a larger rental market might negatively influence the size of the construction sector. This can be explained twofold. First, larger fluctuations in the construction sector during the business cycle induces the need for larger output capacity at all times. Second, the market for owner-occupied housing is flawed by many demand- and supply-side frictions (Czerniak 2016). This might cause oversupply of housing in some market segments, which results also in higher construction output. In turn, the right side of Table 6 shows that the baseline findings for the relation between population growth and construction sector size are also rather robust across estimation methods. The impact of population growth on the size of the construction sector is positive, but falls with an increase in the availability of rental housing and becomes negligible for countries like Germany, Austria or the Netherlands, where rental estates 


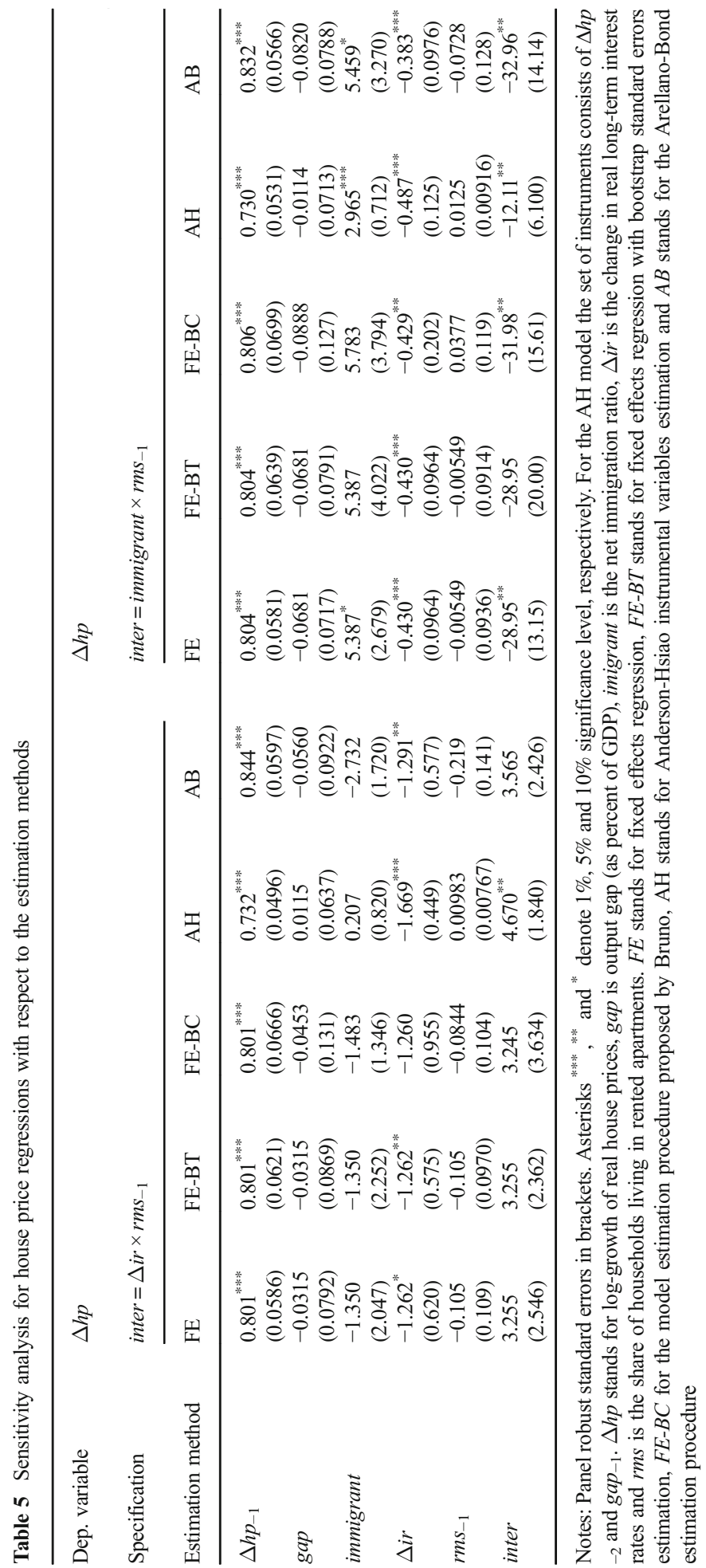




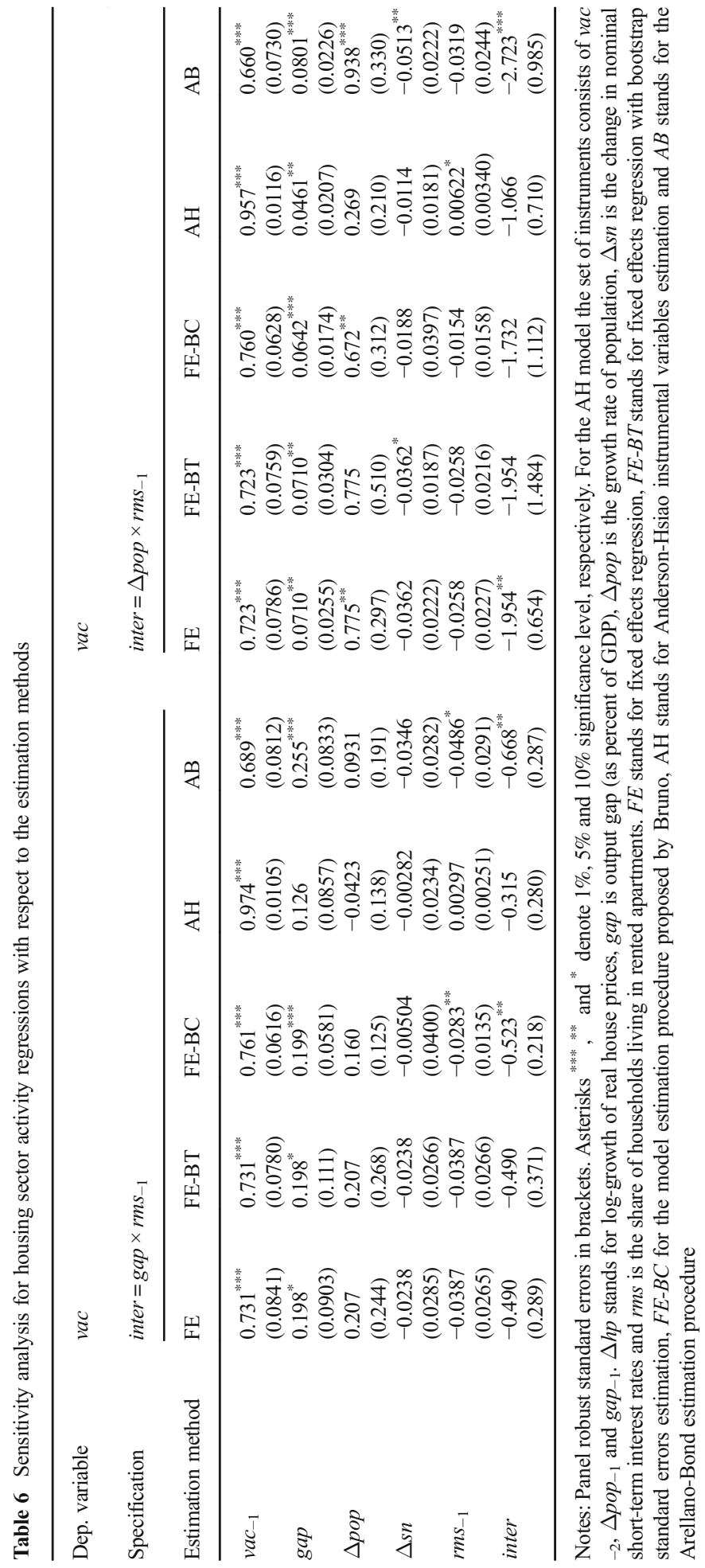


constitute over $40 \%$ of dwellings. In the case of the AB estimation method this relation is especially strong and significant at a $1 \%$ significance level.

\subsection{Results for OECD Countries}

In the second part of the sensitivity analysis we check whether the baseline findings hold if we extend the country coverage for OECD countries outside the EMU. Even though the main aim of the article is to investigate whether the structure of the housing market influences the stability of the EMU, one might be interested if the tenure structure of the housing market influences macroeconomic stability for a broader set of countries. ${ }^{4}$ In general, before we discuss the results it should be noted that non-EMU OECD countries are characterized by relatively heterogeneous financial, cultural and institutional environment in comparison to EMU members, which might have a nonnegligible impact on the estimation results.

Table 7 presents the results for real house price regressions. The left-side columns of the table show that extending the sample for ten non-EMU OECD countries does not change diametrically the baseline results in specification with the monetary interaction variable $\Delta i r \times r m s_{-1}$. Once again, tighter financing conditions are significantly diminishing the pace of house prices growth, but this effect is diminishing (also significantly) with the size of the rental market and is negligible in countries in which the rental share is about one third. However, there are some differences. The autoregressive coefficient estimates are lower, the impact of output gap on house prices is higher and, most importantly, the relationship between house price dynamics and monetary conditions is stronger. It can be noticed that the higher autoregressive coefficient for EMU sample indicates that being a member of the euro area increases the probability of a house price bubble. The intuition behind this result is that higher inflation in a single EMU member state, given an invariant ECB rate, leads to a decrease in the real interest rate, which fuels demand for housing and might further trigger the creation of the bubble. The right side of Table 7 shows that the findings for the demographic interaction variable immigrant $\times r m s_{-1}$ are visibly affected by extending the country coverage. Now the immigration rate becomes uncorrelated with house price dynamics, whatever the size of the rental market is. This result (together with the baseline regression estimates) would indicate that the relationship between demographic variables and house prices is heterogeneous across countries.

The effect of country coverage extension on the results of housing sector activity regressions is presented in Table 8 . The left part of the table shows that parameter estimates of the extended model with the output gap interaction variable gap $\times r m s_{-1}$ are qualitatively comparable to the estimates using the baseline sample of EMU countries. However, now the parameter estimates at the output gap and the interaction variable are higher and the autoregressive coefficient in the dynamic model is somewhat lower. Once again, these results might be interpreted that being a member of the euro area increases the probability of a bubble in the housing sector. Finally, the estimation results of model (2) with the demographic interaction variable $\Delta p o p \times r m s_{-1}$, as shown in the right part of Table 8 , confirm that higher population growth rate has a positive impact on the size of the construction sector only in countries with less developed rental market. However, for all

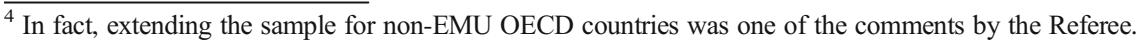


Table 7 Sensitivity analysis for house price regressions with respect to the sample of countries

\begin{tabular}{|c|c|c|c|c|}
\hline \multirow{3}{*}{$\begin{array}{l}\text { Dep. variable } \\
\text { Panel } \\
\text { Specification }\end{array}$} & \multicolumn{4}{|l|}{$\Delta h p$} \\
\hline & \multicolumn{4}{|c|}{22 OECD countries, 1995-2014 } \\
\hline & \multicolumn{2}{|c|}{ inter $=\Delta i r \times r m s_{-1}$} & \multicolumn{2}{|c|}{ inter $=$ immigrant $\times r m s_{-1}$} \\
\hline$\Delta h p_{-1}$ & & $\begin{array}{l}0.593^{\text {**** }} \\
(0.0582)\end{array}$ & & $\begin{array}{l}0.593^{\text {**** }} \\
(0.0625)\end{array}$ \\
\hline gap & $\begin{array}{l}0.864^{* * * *} \\
(0.208)\end{array}$ & $\begin{array}{l}0.266^{*} \\
(0.139)\end{array}$ & $\begin{array}{l}0.871^{\text {***** }} \\
(0.218)\end{array}$ & $\begin{array}{l}0.253 \\
(0.153)\end{array}$ \\
\hline immigrant & $\begin{array}{l}1.302 \\
(2.092)\end{array}$ & $\begin{array}{l}-1.045 \\
(1.368)\end{array}$ & $\begin{array}{l}0.177 \\
(3.973)\end{array}$ & $\begin{array}{l}-0.0943 \\
(2.769)\end{array}$ \\
\hline$\Delta i r$ & $\begin{array}{l}-1.270^{*} \\
(0.634)\end{array}$ & $\begin{array}{l}-1.253^{*} \\
(0.679)\end{array}$ & $\begin{array}{l}-0.148 \\
(0.211)\end{array}$ & $\begin{array}{l}0.0190 \\
(0.231)\end{array}$ \\
\hline$r m s_{-1}$ & $\begin{array}{l}-0.144 \\
(0.235)\end{array}$ & $\begin{array}{l}-0.0683 \\
(0.116)\end{array}$ & $\begin{array}{l}-0.187 \\
(0.234)\end{array}$ & $\begin{array}{l}-0.0846 \\
(0.113)\end{array}$ \\
\hline inter & $\begin{array}{l}3.960 \text { *** } \\
(1.854)\end{array}$ & $\begin{array}{l}4.528^{* * *} \\
(2.112)\end{array}$ & $\begin{array}{l}3.949 \\
(11.91)\end{array}$ & $\begin{array}{l}-3.689 \\
(9.828)\end{array}$ \\
\hline$N$ & 430 & 420 & 430 & 420 \\
\hline
\end{tabular}

Notes: Panel robust standard errors in brackets. Asterisks ***** and denote $1 \%, 5 \%$ and $10 \%$ significance level, respectively. Non-EZ OECD countries include: Australia, Canada, Denmark, Japan, Korea, New Zealand, Norway, Sweden, Switzerland, United Kingdom, United States. OECD countries include apart from the above: Austria, Belgium, Finland, France, Germany, Greece, Ireland, Italy, Luxembourg, Netherlands, Portugal, Spain

OECD countries this relationship is statistically significant (at a 5\% level) only in the static specification. In the dynamic specification the estimated parameters are of expected sign but not statistically significant at any reasonable level.

To summarize, for the sample of EMU countries the baseline results for dynamic models (1) and (2) are robust with respect to the choice of the estimation method. In particular, for countries with relatively high share of the rental market, amounting to $30-40 \%$, the housing sector is relatively resistant to changes in monetary conditions, demographic developments or business cycle fluctuations. In turn, extending the sample for ten non-EMU OECD countries strengthens the estimated relationship between monetary conditions and house prices as well as between output gap and construction sector activity. On the contrary, in a larger sample of countries the impact of demographic variables on the housing market seems to be less pronounced.

\section{Conclusions and Policy Implications}

In this paper we have investigated whether the size of the rental market affects fluctuations of house prices and the activity in the construction sector over the business cycle. We have found that there is a statistically significant relationship between the size of the rental market and the responsiveness of the housing sector to demand fluctuations and macroeconomic shocks. In particular, the estimation results indicate that an increase of the rental market share to levels exceeding $40 \%$ might lead to a situation in which the housing sector becomes a stabilizer of the economy. It can be noted that this finding is partially confirmed by observation that the Austrian and 
Table 8 Sensitivity analysis for housing sector activity regressions with respect to the sample of countries

\begin{tabular}{|c|c|c|c|c|}
\hline \multirow{3}{*}{$\begin{array}{l}\text { Dep. variable } \\
\text { Panel } \\
\text { Specification }\end{array}$} & \multicolumn{4}{|l|}{$v a c$} \\
\hline & \multicolumn{4}{|c|}{22 OECD countries, 1995-2014 } \\
\hline & inter $=$ gap & & inter $=\Delta_{l}$ & \\
\hline$v a c_{-1}$ & & $\begin{array}{l}0.523^{* *} \\
(0.242)\end{array}$ & & $\begin{array}{l}0.522^{* *} \\
(0.234)\end{array}$ \\
\hline gap & $\begin{array}{l}0.436^{\text {**** }} \\
(0.0733)\end{array}$ & $\begin{array}{l}0.278^{* *} \\
(0.128)\end{array}$ & $\begin{array}{l}0.106^{\text {***** }} \\
(0.0340)\end{array}$ & $\begin{array}{l}0.0606^{\text {*** }} \\
(0.0188)\end{array}$ \\
\hline$\Delta p o p$ & $\begin{array}{l}1.127^{* * *} \\
(0.256)\end{array}$ & $\begin{array}{l}0.406^{*} \\
(0.236)\end{array}$ & $\begin{array}{l}3.139^{\text {**** }} \\
(0.755)\end{array}$ & $\begin{array}{l}1.758 \\
(1.170)\end{array}$ \\
\hline$\Delta s n$ & $\begin{array}{l}-0.0501 \\
(0.0483)\end{array}$ & $\begin{array}{l}0.00534 \\
(0.0265)\end{array}$ & $\begin{array}{l}-0.0574 \\
(0.0496)\end{array}$ & $\begin{array}{l}0.000868 \\
(0.0262)\end{array}$ \\
\hline$r m s_{-1}$ & $\begin{array}{l}-0.0612 \\
(0.0359)\end{array}$ & $\begin{array}{l}-0.0412 \\
(0.0245)\end{array}$ & $\begin{array}{l}-0.0252 \\
(0.0319)\end{array}$ & $\begin{array}{l}-0.0176 \\
(0.0234)\end{array}$ \\
\hline inter & $\begin{array}{l}-1.103^{* * *} \\
(0.248)\end{array}$ & $\begin{array}{l}-0.726^{*} \\
(0.384)\end{array}$ & $\begin{array}{l}-6.620^{* *} \\
(2.575)\end{array}$ & $\begin{array}{l}-4.457 \\
(3.353)\end{array}$ \\
\hline$N$ & 441 & 433 & 441 & 433 \\
\hline
\end{tabular}

Notes: Panel robust standard errors in brackets. Asterisks ${ }^{* * * * *}$ and ${ }^{*}$ denote $1 \%, 5 \%$ and $10 \%$ significance level, respectively. Non-EZ OECD countries include: Australia, Canada, Denmark, Japan, Korea, New Zealand, Norway, Sweden, Switzerland, United Kingdom, United States. OECD countries include apart from the above: Austria, Belgium, Finland, France, Germany, Greece, Ireland, Italy, Luxembourg, Netherlands, Portugal, Spain

German economies, which are characterized by relatively developed rental markets, have been most stable in EMU for the last two decades.

This study provides some important implications for economic policy at EMU level. In particular, it indicates that differences of housing tenure structure among monetary union countries might lead to heterogeneous response to common shocks or common monetary policy. This, in turn, might lead to business cycle divergence. This claim is well illustrated by the developments in the housing market in Ireland and Spain. The decline in the interest rates after joining the EMU triggered a housing boom, which turned into a harmful bust during the recent crisis. Our analysis suggests that if rental houses in those countries were more common the volatility of these economies would be lower.

A straightforward implication of our results for the economic policy is that it is justified to support the expansion of the rental market. In this paragraph we provide a short list of issues that should be considered in this kind of policy. First, it is important to create condition in which the economic costs of owning and renting are comparable or even tilted towards renting. For instance, Gervais (2002) uses a life-cycle model to assess how changes in taxation affect the housing tenure decision to find that eliminating a subsidy to house purchases and the introduction of subsidies to rental payments increase the rental market share. Second, it is important to remember that the tenure choice is strongly affected by non-financial factors. It can be claimed that households derive greater utility from living in an owned rather than rented apartment, as confirmed by the empirical studies of Elsinga and Hoekstra (2005) and Diaz-Serrano (2009). In this respect it is important to create conditions in which property owners are considering renting as an acceptable alternative. This can be achieved by developing regulations stimulating demand for renting, e.g. in which tenants are protected 
against unexpected rent increases or unjustified eviction so that they could "feel at home". It should be noted, however, that measures stimulating demand for renting should also support the supply of houses to rent: the risk profile and rate of return on investing in houses to let must be attractive in comparison to other forms of locating capital. In this sense regulations that excessively protect tenants might be counterproductive. Equalizing utility from renting and owning might be also supported by stimulating the professionalization of rental services, e.g. by encouraging professional investors that specialize in managing and building rental housing, but also by supporting associations of individual landlords or rental management companies. Finally, in the context of EMU it can be mentioned that even if housing policy among the member states was exactly the same, the tenure structure differences might persist. The reason is that tenure preferences are also determined by cultural factors. For example, in the Anglo-Saxon countries owning a house is a sign of economic success in a much more pronounced way than in German-speaking countries (Elsinga and Hoekstra 2005).

Acknowledgements This project was financed by the National Science Centre grant No. 2014/15/B/HS4/ 01382. It benefited from comments from participants to the ISCEF (Paris, April 2016) and Macromodels 2016 (Lodz, November 2016) conference as well as from the comments by an anonymous Referee, the Editor-inChief, and the Guest Editor. The views expressed in this paper are those of the authors and do not necessarily reflect those of the institutions to which they are affiliated.

Open Access This article is distributed under the terms of the Creative Commons Attribution 4.0 International License (http://creativecommons.org/licenses/by/4.0/), which permits unrestricted use, distribution, and reproduction in any medium, provided you give appropriate credit to the original author(s) and the source, provide a link to the Creative Commons license, and indicate if changes were made.

\section{References}

Agnello L, Schuknecht L (2011) Booms and busts in housing markets. Determinants and implications. J Hous Econ 20(3):171-190

Ambrose BW, Eichholtz P, Lindenthal T (2013) House prices and fundamentals: 355 years of evidence. J Money Credit Bank 45(2-3):477-491

Anderson T, Hsiao C (1982) Formulation and estimation of dynamic models using panel data. J Econ 18(1): 47-82

André C, Girouard N (2009) Housing markets, business cycles and economic policies. Chapter 6, In: Arestis P, Mooslechner P, Wagner K (Eds.) Housing market challenges in Europe and the United States, Palgrave Macmillan, Basingstoke, United Kingdom, p 109-130

Andrews D, Caldera Sánchez A, Johansson A (2011) Housing markets and structural policies in OECD countries. OECD Economics Department Working Papers 836, Paris, France

Arce ÓJ, López-Salido D (2011) Housing bubbles. Am Econ J Macroecon 3(1):212-241

Arellano M, Bond S (1991) Some tests of specification for panel data: Monte Carlo evidence and an application to employment equation. Rev Econ Stud 58(2):277-297

Barceló C (2006) Housing tenure and labour mobility: a comparison across European countries. Banco de Espana Documentos de Trabajo 0603, Madrid, Spain

Bernanke BS, Gertler M, Gilchrist S (1996) The financial accelerator and the flight to quality. Rev Econ Stat 78(1):1-15

Blanchflower DG, Oswald AJ (2013) Does high home-ownership impair the labor market? National Bureau of Economic Research Working Paper 19079, Cambridge MA, United States

Bruno GS (2005) Estimation and inference in dynamic unbalanced panel-data models with a small number of individuals. Stata J 5(4):473-500 
Caldera Sánchez A, Andrews D (2011) To move or not to move: what drives residential mobility rates in the OECD? OECD Economics Department Working Papers 846, Paris, France

Caldera Sánchez A, Johansson A (2011) The price responsiveness of housing supply in OECD countries. OECD Economic Department Working Papers 837, Paris, France

Case KE, Quigley JM, Shiller RJ (2005) Comparing wealth effects: The stock market versus the housing market. The B.E. J Macroecon 5(1):1-34

Catte P, Girouard N, Price R, André C (2004) Housing markets, wealth and the business cycle. OECD Economics Department Working Papers 394, Paris, France

Conefrey T, Gerald JF (2010) Managing housing bubbles in regional economies under EMU: Ireland and Spain. Natl Inst Econ Rev 211(1):91-108

Crowe C, Dell'Ariccia G, Igan D, Rabanal P (2013) How to deal with real estate booms: Lessons from country experiences. J Financ Stab 9(3):300-319

Cuerpo C., Kalantaryan S, Pontuch P (2014) Rental market regulation in the European Union. European Economy, Directorate General Economic and Financial Affairs Economic Papers 515, European Commission, Brussels, Belgium

Czerniak A (2014) Wpływ cech społeczno-kulturowych społeczeństw na powstawanie baniek cenowych na rynku mieszkaniowym. PhD dissertation at SGH Warsaw School of Economics, supervisor R. Rapacki, Warsaw, Poland

Czerniak A (2016) Why are housing markets prone to price bubbles? Unpublished manuscript, Warsaw, Poland

Czerniak A, Witkowski B (2016) Model wczesnego ostrzegania przed bańkami cenowymi na rynku mieszkaniowym. Materiały i Studia Narodowego Banku Polskiego 326, Warsaw, Poland

Diaz-Serrano L (2009) Disentangling the housing satisfaction puzzle: Does homeownership really matter? J Econ Psychol 30(5):745-755

Elsinga M, Hoekstra J (2005) Homeownership and housing satisfaction. J Housing Built Environ 20(4): $401-424$

Farrar DE, Glauber RR (1967) Multicollinearity in regression analysis: the problem revisited. Rev Econ Stat 49(1):92-107

Favara G, Imbs J (2015) Credit supply and the price of housing. Am Econ Rev 105(3):958-992

Gervais M (2002) Housing taxation and capital accumulation. J Monet Econ 49(7):1461-1489

Gete P (2010) Housing markets and current account dynamics. MPRA Paper 20957, Munich, Germany

Glaeser EL, Gyourko J, Saiz A (2008) Housing supply and housing bubbles. J Urban Econ 64(2):198-217

Iacovello M, Minetti R (2008) The credit channel of monetary policy: Evidence from the housing market. J Macroecon 30(1):69-96

IMF (2009) Spain: selected issues. International Monetary Fund, Washington DC, United States

Kofner S (2014) The German housing system: Fundamentally resilient? J Housing Built Environ 29(2): 255-275

Leamer EE (2007) Housing is the business cycle. National Bureau of Economic Research Working Paper 13428, Cambridge MA, United States

Maclennan D, Muellbauer J, Stephens M (1998) Asymmetries in housing and financial market institutions and EMU. Oxf Rev Econ Policy 14(3):54-80

Mills ES (1990) Housing tenure choice. J Real Estate Financ Econ 3:323-331

Nelder JA (1998) The selection of terms in response-surface models: How strong is the weak-heredity principle? Am Stat 52(4):315-218

Nickell S (1981) Biases in dynamic models with fixed effects. Econometrica 49(6):1417-1426

OECD (2005) Recent house price developments: the role of fundamentals. In: OECD Economic Outlook 78 (pp. 123-153), Paris, France

Rubaszek M, Rubio M (2017) Does rental housing market stabilize the economy? A micro and macro perspective. Warsaw, Poland. Unpublished manuscript, URL: http://web.sgh.waw.pl/ mrubas/Publikacje/HousingDSGE RR2017.pdf

Rubio M (2014) Housing-market heterogeneity in a monetary union. J Int Money Financ 40(C):163-184

Sinai T, Souleles NS (2005) Onwer-occupied housing as a hedge against rent risk. Q J Econ 120(2):763-789 